\title{
No Assignment for Cowards: What Is to Be Gained through Interdisciplinary Research?
}

\author{
Maria Fusco
}

\begin{abstract}
:
This text explores the uses of interdisciplinarity as a form of ethical cohabitation utilising my directorship of the seminal programme "MFA Art Writing" at Goldsmiths, University of London, as case-study.
\end{abstract}

In 2008, when I set about animating the new, academic format that Goldsmiths had constructed to be able to employ me, I felt like a taxidermist who had just succeeded in stuffing a leopard realistically.

I devised and led MFA Art Writing at Goldsmiths, University of London. It was the first programme of its kind internationally drawing diverse artistic, literary, and theoretical actants to its corps and to teach writing as a studio practice. We were stationed in an art department: universities do, after all, often administratively and interiorly resemble militarist compounds.

Working with my three new, esteemed, colleagues-Yve Lomax, Michael Newman, and Adrian Rifkin - who were as fresh as I to the 'proper-naming' of this new academic subject area of art writing - I began to notice I was writing the word 'negotiate' a lot more than I ever had done before, in university papers and emails. I even learned to spell it correctly through repetition; another word I still find hard to spell.

Before we started working with students, I had six months to pick apart what writing as contemporary art, what writing as practice meant, and, to write a programme which could actually teach it. I knew we had to be clarion. There were no exemplars to draw from; this did not suit me. At that time, I would have preferred if there had been a concurrent programme, which I despised, so I could drool over, lacerate, and improve upon it. When MFA Art Writing eventually ceased, I noted, with some surprise, that colleagues from subsequent like-minded programmes in different institutions did exactly this, and realised it to be an ugly tactic: from this I have learnt there is no shame in dreaming.

I have read that the invention of a new tool is an act of frustration: this, I know to be true. Over the programme's lifespan, many tiny, pedagogic tools 
of special manufacture were needed to tease, tweak, ratchet, and knock our teaching methods into fit purpose. It was essential to keep snagging.

MFA Art Writing quickly recruited a tight cohort of talented, hardworking, and determined students; we collaborated to define what art writing might be (my preferred phrase) through actually doing it. I did not believe in giving postgraduate students briefs to work on; rather I invited students to come with a research project that the programme would engage with critically and improve through teaching: in this way the MFA had the research characteristics of doctoral study. This collaborative method of aporetic working is marvellously productive when everyone shares with an open heart, a brimming brain, and a harsh tongue: this moment is the luxury of starting something new with excellent people.

In order to facilitate aporia, it was essential not to be sure. To communicate this uncertainty with confidence through practice, with authentic scholarly rigour, outwith of the bushed infrastructural support of legislative academic context was the vulnerable aim.

Over the years, students sought out the programme from undergraduate disciplines including fine art, literature, music, politics, theatre, and visual theory. Most were entirely dissatisfied with what they had got in their undergraduate education and somehow wanted more. The former art students felt their writing had not been taken seriously in a studio context but, for the first semester, they mourned the death of the art object. The former literature students felt experimental modes of writing had been smothered in favour of a linear plot but, for the first semester, they insisted on knowing how it was all going to end. The former music students felt distinct critical writing methods were needed to hear properly but, for the first semester, they asked why everything was so quiet. The former politics students felt the erosion of noble concept but, for the first semester, insisted on authenticity. The former theatre students felt characterisation was over-rated anyway but, for the first semester, did not read out their work in their real voice. The former visual theory students felt motif was anti-ideological but, for the first semester, proposed a diagrammatic answer to each rhizomatic problem.

What was at stake in the first few months of the students participating in the programme-the multivarious bereavement of decontextualisationwas, I believe, the polygamy of discipline seeking the harmonious relationship of mutual benefit. To pinch a clichéd 'university' word, this was challenging in the extreme, for all of us. To be precise, what was challenging was exactly this: What is to be gained through interdisciplinary research? This question will never be exhausted. I will pose it again: What is to be gained through interdisciplinary research? 
My favoured answer to this question is that to be the amateur is vastly preferable to being the professional, for the amateur proceeds with alacrity and resourcefulness. By its nature, interdisciplinary research renders each of us precarious, each of us the amateur-by necessitating as it does adaptation across discipline boundary. And here, I mean intelligent adaptation which is not reactionary but rather purposefully generous.

This situated approach to how MFA Art Writing worked, at its core the entanglement of words through the fields of art and literature, was a temporal imperative, not a taxonomical, one. There is currently still no satisfactory definition of 'art writing' - I am often asked to provide one; I will not - it is still a contested term. The most sincere expression of art writing as a field is found in the galore works of those who practise it.

Coming to writing this text and again considering why I wilfully choose to situate not only my research but also my current teaching as interdisciplinary I am drawn to the word I used in a previous paragraph: that word is 'generous.' For generosity is crucial to successful, propagative interdisciplinarity research because it articulates and then tends to an ethics of cohabitation, by ensuring that the assembled group take individual, not individuated, responsibility to communicate effectively and to listen with care. When interdisciplinary groups come together in this way the plural pronoun-'the we'-is not embarrassed to admit that we are unsure, despite abundant confluent knowledge, 'the we' must each time start anew, not knowing how to finish.

I witnessed this.

*Postscript: I have decided not to include any references for this text—although clearly my thinking is not autogenetic, and is informed by voices other than my own-because I want the text to stand alone, as my opinion, not as conceit. 